\title{
Uncovering interest group participation in Germany: web collection of written statements in ministries and the parliament
}

\author{
Daniel Rasch ${ }^{1}$ (D) Florian Spohr ${ }^{2} \cdot$ Rainer Eising $^{2} \cdot$ Simon Ress $^{2}$
}

Published online: 1 August 2020

(c) The Author(s) 2020

\begin{abstract}
This article discusses web collection of interest group statements on bills as a data source. Written statements allow the identification of actors active in policy-making as well as those actors' positions, lobbying coalitions and issue saliency. These data also can contribute to the measurement of interest groups' influence on legislation. Taking web collection from the German parliament's and ministries' web pages as an example, we demonstrate the collection process and the merits and limitations of employing written statements as identificatory data. Our analysis of statements submitted by interest groups, private firms and policy experts to four federal ministries and the respective parliamentary committees in the years 2015 and 2016 reveals differences between parliamentary and ministerial consultations. Although ministries have invited written statements for fewer draft laws than parliamentary committees, they received far more statements from interest groups. The reason is that German ministries often issue open calls, in which all actors are given the opportunity to comment on legislation, whereas the German parliament invites selected interest group representatives and other experts. As a further result, ministries are mostly contacted by business groups, whereas parliamentary committees use their gatekeeper function to balance interests.
\end{abstract}

Keywords Consultations · Lobbying · Ministries · Parliament · Web collection · Written statements

Daniel Rasch

rasch@foev-speyer.de

1 Chair of Political Science, German University of Administrative Sciences Speyer,

Freiherr-vom-Stein-Straße 2, 67346 Speyer, Germany

2 Chair of Comparative Politics, Ruhr-University Bochum, Universitätstraße 150, 44801 Bochum, Germany 


\section{Introduction}

Interest group research widely considers interest mediation as an exchange of information between decision-makers and stakeholders. The underlying assumption is that external information helps decision-makers to increase the quality and the legitimacy of their decisions, sway public opinion, raise awareness and even secure budgets (Beyers et al. 2008; Beyers 2004; Yackee 2006). One key institutionalized and formalized way for ministries and parliaments to receive information from external actors is through written statements, understood as position papers that interest groups and other mobilized actors submit during the policy process (Rasmussen 2015).

Written statements include different types of information. They can inform about the technical characteristics and potential consequences of a given policy. Statements can lay out the positions of actors and provide feedback for decision-makers on the opposition and support a policy might face. Different decision-makers demand these types of information in different phases of the policy-making process. Bureaucrats draft the details of bills and may be most welcoming of technical information. Members of Parliament are subject to electoral constraints and may be more interested in political information that can assist their reelection, as well as in information about how a policy relates to wider political priorities (Burstein and Hirsh 2007; Sabatier and Whiteman 1985)

Several studies have used written statements as a data source, employing qualitative (Eising et al. 2015, 2017) or quantitative content analyses (Klüver and Mahoney 2015; Bunea and Ibenskas 2015) or both (Boräng et al. 2014). Some studies compare written statements in different countries or political systems, like Britain and Australia (Manwaring 2014), Denmark and the UK (Rasmussen 2015) or Germany, the Netherlands, Sweden and the UK (Eising et al. 2015, 2017; Rasch 2018). Other studies focus on the role of written statements in a single political system, such as Japan (Schwartz 1998), Germany (Eising and Spohr 2017), the USA (Baumgartner et al. 2009b) or the European Union (Rasmussen and Carroll 2014; Klüver 2013).

In the following sections, we will outline the research options written statements offer as a data source. We then illustrate how written statements fit in Germany's legislative procedure and discuss the results of the collection process. We believe that this paper contributes to the research on written statements by comparing the usage of those in two branches at the same time. The reason is that Germany has recently changed its transparency rules and written statements are, for the first time, publicly available for the bureaucracy as well as the legislature.

\section{Research options of analyzing written statements}

We highlight five insights researchers can derive from collecting written statements. First, collecting written statements allows researchers to identify the actors engaged in policy-making. Provided that statements are not anonymized and can be linked to the actors that gave the statements, collecting and gathering the names of the authors 
allows mapping the population of interest groups and other stakeholders commenting on a bill. A variety of actors submit written statements to ministries and parliamentary committees, among others business groups, labor unions, public interest groups, corporations and policy experts. There are different schemes to sort these actors into distinct categories. The schemes are based on behavior, organizational features or the self-identification by interest groups (Baroni et al. 2014). Classifying stakeholders enables researchers to find out whether interest group participation is balanced or biased toward certain types of interests or actors (Pedersen et al. 2015), whether it varies over time, across policy issues (Dhungel and Linhart 2014), and in different types of consultations. Regarding the latter, a closed consultation based on invitations will attract a certain set of stakeholders and, usually, a smaller set than an open consultation (Pedersen et al. 2015).

It is also important to bear in mind that public consultations are not the only access point of interest groups to politicians and bureaucrats. The study of informal access must complete the analysis of formal consultations to not miss important actors and to establish the relevance of different access points.

Secondly, in an open consultation, the number of submitted statements can indicate the salience of an issue. Salience denotes how important a policy issue is to an actor or how much attention the actor devotes to the issue (Klüver 2011). Most actors do not wish to and also lack resources to comment on every policy issue. Rather, they will concentrate on policy proposals that are of higher interest or importance to them. Therefore, the number of mobilized actors can indicate issue salience.

Thirdly, written statements can help to identify (a) the positions of their authors regarding specific policy proposals, (b) the type of information they provide and (c) the frames they use.

Written statements tend to be position papers, in which actors express their support of or opposition toward a policy proposal or the issues included in the bill. However, not all actors position themselves in the written statements, in particular policy experts may limit themselves to providing neutral evidence that they were asked to contribute.

Methodologically, positions as well as the frames and arguments that support these positions have been identified by means of qualitative content analyses that employ human (computer assisted) coding on the basis of codebooks (Eising et al. 2015) or as automated (or semi-automated) quantitative content analyses (Klüver and Mahoney 2015). Several comparisons of these methods point to their strengths and weaknesses (Boräng et al. 2014). In quantitative content analysis, heterogeneity and technicality of the data may pose a problem since homogeneous (comparable) data are needed. The size, length, structure-and in consultations on European Union policies also the language — can vary hugely. In addition, factual density and high technicality incorporated in some written statements complicate their analysis and comparison. There are different ways for measuring the positions of the actors. Studies that resort to the manual coding of positions tend to employ an ordinal scaling, for example a three-point ordinal scale (negative, neutral, positive) (Wonka 2016) or a five-point Likert scale (fully against the bill, significant objections against the bill, policy expertise without taking position, general support with objections against parts of the bill, full support of the bill) (Cross et al. 2019). 
Fourthly, written statements enable us to identify lobbying coalitions. It is not uncommon that organizations with a shared interest submit a joint statement or send separate statements that deliver the same message. Therefore, the actors can pool their resources or stress the importance of their demands with the help of coalitions. Coalitions that have been identified based on written statements are, on the one hand, informal as being on the same side of a policy discussion, but not formally engaged in a coalition (Klüver 2013) or, on the other hand, as formalized coalitions with clear statements to support each other (Baumgartner et al. 2009a).

Lastly, analyzing written statements can aid measuring interest groups' success and influence by triangulating data or methods. An often-used method to gauge lobbying success is the preference attainment approach (Dür 2008). Using spatial modeling and based on the proximity of actors' policy positions to those of the policy's status quo, policy output and reversion point, this approach is employed to draw conclusions about winners and losers in the policy-making process. Preference attainment of interest groups can also be measured by comparing the positions in written comments or interviews with amendments made to the legislative draft (Dür et al. 2015; Rasch 2018). Other studies assess interest groups' influence on law-making by measuring whether their statements are associated with amendments made to the policies under discussion (Cross et al. 2019).

\section{Written statements in the German legislation}

We use Germany as an example to illustrate the web collection process of written statements, as well as the characteristics of the collected data. First, we identify the actors, the actor types and the distribution of the data across both branches of government.

The legislative process in Germany typically starts with a ministerial draft bill. The leading ministry decides whether a consultation with external actors is needed and consults actors on a draft bill (so-called Referentenentwurf). Paragraph 47 of the Joint Rules of Procedure of the Federal Ministries (Gemeinsame Geschäftsordnung der Bundesministerien (GGO)) defines how German federal ministries can collect information from external actors ranging from interest groups to public institutions. It is at the discretion of the leading ministry to decide whom to contact, when and how. Federal ministries can use both open and closed consultations. In closed consultations, the leading ministry selects the stakeholders beforehand and requests written statements from them. However, ministries do not always ignore written statements that were submitted to these consultations without request. ${ }^{1}$ In open consultations, there are general requests for written statements.

After the consultation, the ministerial draft is discussed in the cabinet and after agreement submitted to the legislative institutions, the Bundesrat (representative institution of the Länder) and the Bundestag (parliament's first chamber and core

\footnotetext{
${ }^{1}$ In some statements, the authors thank other organizations for forwarding the drafted bill to them since they have not been contacted directly by the ministry to comment on the bill.
} 
legislative institution). After its first reading in the Bundestag, the plenary refers it to the relevant standing committee. Committees tend to mirror government departments and are entitled to propose amendments of bills to the plenary. They cannot themselves pass amendments or veto the bill. But they have the right to hold public hearings on bills and to invite representatives of interest groups, policy experts and other actors to these hearings. In preparation of such a hearing, "the committee may request the persons furnishing information to submit written comments" (Rule 70 (6) Rules of Procedure of the German Bundestag-Geschäftsordnung des Bundestags). Participation in consultations is limited to invited actors even though some committees admit submissions from actors not invited.

The Parliamentary Material Information System $(D I P)^{2}$ provides information on the legislative process as well as links to major documents. The web pages of the permanent committees ${ }^{3}$ collate the written statements they have received. Statements are available online from the year 2002 onwards. (The Bundestag administration is digitizing older hearings.) For earlier years, the Bundestag's archives must be searched. Most analyses that employ these data sources aim at identifying the access and input of interest groups to German legislation (Sack and Fuchs 2014; Dhungel and Linhart 2014). Others connect their presence and positions in parliamentary hearings to legislative output to establish in how far legislative change corresponds with interest groups' preferences (Cross et al. 2019; Eising and Spohr 2017).

By contrast, the publication of written statements submitted by stakeholders to ministries is a very recent development in Germany. Therefore, there are very few studies on this topic. An INTEREURO project (Beyers et al. 2014) researched written statements in the German ministries in relation to EU legislation, examining 20 EU directives (Eising et al. 2015, 2017). Further studies that draw on written statements as a data source focus on specific policy domains, such as a study on lobbyism in climate protection (Gründinger 2012).

Written statements submitted to ministries can be collected online through a new web page containing links to all ministries' consultation pages. ${ }^{4}$ For each bill, the written statements (Stellungnahmen) can be downloaded as pdf files, including the ministerial draft (Referentenentwurf, literally, the referent's draft). However, statements can only be collected if the respective leading ministry has published its ministerial draft, which has only been obligatory for ministries from 2017 onwards. Furthermore, German data protection laws form a rather specific obstacle: Stakeholders can ask for their data to be protected so that their written statements will be anonymized before being uploaded by a government ministry.

\footnotetext{
${ }^{2}$ http://dipbt.bundestag.de/dip21.web/bt, last accessed 30th April 2020.

3 https://www.bundestag.de/ausschuesse, last accessed 30th April 2020.

${ }^{4}$ https://www.bundesregierung.de/breg-de/service/gesetzesvorhaben, last accessed 30th April 2020.
} 


\section{Descriptive data analysis}

In the following section, we present descriptive statistics on written statements that various actors submitted to four German ministries and committees in the years 2015 and 2016. We selected these years based on a relevance sampling strategy, since at the time of writing, there were no other comparable years for the two government branches available (Krippendorff 2004: 118-120). These were the only consultations and invitations which were fully uploaded and up to date.

Our data cover statements from the Federal Ministry for the Environment, Nature Conservation, Housing and Nuclear Safety (BMU), the Federal Ministry of the Interior (BMI), the Federal Ministry of Finance (BMF) and the Federal Ministry of Health (BMG), as well as the committees mirroring these ministries: Finance,

Health, Internal Affairs and Environment, Nature Conversation, Housing and Nuclear Safety.

All written statements were downloaded, and the authors' names were retrieved. Each author was classified using any of seven categories: (1) business groups, (2) public interest groups, (3) unions, (4) occupational associations, (5) policy experts, (6) private firms and (7) others. This coding scheme is a slightly amended version of the INTERARENA classification scheme (Baroni et al. 2014; Binderkrantz et al. 2015) which is based on an organizational definition of interest groups. Also, we assigned an identification number to each actor, each written statement and each bill.

We generated two datasets: The first includes statements on all bills discussed in the four ministries and parliamentary committees in the years 2015 and 2016. The second dataset zooms in on those bills only which were subject of consultation in both ministries and parliamentary committees $(\mathrm{N}=24)$. This allows us to compare the bill-related lobbying activity of actors across branches of government enabling us to single out which actors submitted statements only to parliament, only to ministries and to both branches.

Table 1 presents the mobilization of actors on 229 bills. Parliament set up hearings on 156 bills, and government ministries organized consultations on 97 bills. There was a total of 253 bill-related consultations on 229 distinct bills. Twenty-four bills (10.5\% of all distinct bills) were the subject of consultations in both parliament and government. Overall, we collected 3207 statements. Of these, 1696 were submitted to the ministries and 1511 to the parliament. Each actor accounts for 2.0 statements on average (2.1 in ministries and 1.8 in parliament). Co-authored statements - the reason for the difference between the total sum of statements and the amount of distinct statements - are a rarity: $1 \%$ of the statements that were submitted to ministries were co-authored, and $0.7 \%$ of the statements were presented in parliament. Variations across actor types in that regard are minimal. Based on the written statements, we identified 1689 distinct actors. In total, 912 actors submitted statements to the ministries and 880 to parliamentary committees. In total, 103 actors $(6.1 \%$ of all distinct actors) were active in both branches.

The mean number of statements on a bill was 17.5 in ministries compared to 9.7 in parliament. Thus, parliamentary committees seem to use their gatekeeper function to invite fewer stakeholders to comment on a bill than are present in government 
Table 1 All bills in 2015 and 2016. Source: Ministry's websites (BMU, BMI, BMF, BMG) and parliamentary committees' websites (Finance Committee, Committee on Health, Committee on Internal Affairs, Committee on the Environment, Nature Conversation, Housing and Nuclear Safety); own calculations

\begin{tabular}{|c|c|c|c|c|c|c|c|c|c|}
\hline \multirow[t]{2}{*}{ Actor type } & \multicolumn{2}{|c|}{$\begin{array}{l}\text { Written } \\
\text { statements }\end{array}$} & \multicolumn{2}{|c|}{ Bills $^{\mathrm{a}}$} & \multicolumn{2}{|c|}{$\begin{array}{l}\text { Distinct } \\
\text { actors }\end{array}$} & \multirow{2}{*}{$\begin{array}{l}\text { Mean number } \\
\text { of statements } \\
\text { on a bill } \\
\varnothing\end{array}$} & \multirow{2}{*}{$\begin{array}{l}\text { Mean number } \\
\text { of statements } \\
\text { by actor } \\
\varnothing\end{array}$} & \multirow{2}{*}{$\begin{array}{l}\text { Mean number } \\
\text { of actors by } \\
\text { statement } \\
\varnothing\end{array}$} \\
\hline & $N$ & $\%$ & $N$ & $\%$ & $N$ & $\%$ & & & \\
\hline Ministries & 1696 & - & 97 & - & 912 & - & 17.5 & 2.1 & 1.11 \\
\hline Unions & 73 & 4.3 & 38 & 39.2 & 12 & 1.3 & 1.9 & 6.1 & 1.00 \\
\hline $\begin{array}{r}\text { Business } \\
\text { groups }\end{array}$ & 796 & 46.9 & 80 & 82.5 & 358 & 39.3 & 10.0 & 2.5 & 1.12 \\
\hline $\begin{array}{l}\text { Occupational } \\
\text { groups }\end{array}$ & 332 & 19.6 & 66 & 68.0 & 164 & 18.0 & 5.0 & 2.2 & 1.06 \\
\hline $\begin{array}{l}\text { Public inter- } \\
\text { ests }\end{array}$ & 279 & 16.5 & 58 & 59.8 & 202 & 22.2 & - & 1.6 & 1.19 \\
\hline Private firms & 45 & 2.7 & 24 & 24.7 & 45 & 4.9 & 1.9 & 1.0 & 1.04 \\
\hline Policy experts & 8 & 0.5 & 6 & 6.2 & 8 & 0.9 & 1.3 & 1.00 & 1.00 \\
\hline Others & 180 & 10.6 & 55 & 56.7 & 123 & 13.5 & 3.3 & 1.5 & 1.04 \\
\hline Parliament & 1511 & - & 156 & - & 880 & - & 9.7 & 1.8 & 1.04 \\
\hline Unions & 76 & 5.0 & 50 & 32.1 & 14 & 1.6 & 1.5 & 5.4 & 1.00 \\
\hline $\begin{array}{r}\text { Business } \\
\text { groups }\end{array}$ & 365 & 24.2 & 100 & 64.1 & 155 & 17.6 & 3.7 & 2.4 & 1.03 \\
\hline $\begin{array}{l}\text { Occupational } \\
\text { groups }\end{array}$ & 203 & 13.4 & 66 & 42.3 & 105 & 11.9 & 3.1 & 2.0 & 1.02 \\
\hline $\begin{array}{l}\text { Public inter- } \\
\text { ests }\end{array}$ & 242 & 16.0 & 90 & 57.7 & 120 & 13.6 & 2.7 & 2.1 & 1.02 \\
\hline Private firms & 73 & 4.8 & 46 & 29.5 & 58 & 6.6 & 1.6 & 1.3 & 1.00 \\
\hline Policy experts & 352 & 23.3 & 127 & 81.4 & 292 & 33.2 & 2.8 & 1.2 & 1.00 \\
\hline Others & 210 & 13.9 & 106 & 68.0 & 136 & 15.5 & 2.0 & 1.7 & 1.12 \\
\hline $\begin{array}{l}\text { Overall and } \\
\text { distinct }\end{array}$ & 3207 & - & 229 & - & 1689 & - & 14.0 & 2.0 & 1.08 \\
\hline
\end{tabular}

${ }^{a}$ Total number and proportion of bills in which at least one actor (per actor type) was active. We have 24 bills that were discussed in both branches. This is why the overall and unique number of bills does not add up to 229 unique bills

consultations. We may expect this pattern because ministries tend to request written statements in open consultations. The Bundestag's committees face greater time constraints in their proceedings than the ministries.

The number of actors per statement differs between ministries and parliament as well. On average, a statement sent to a ministry is written by 1.1 actors. By comparison, an average statement submitted to a parliamentary hearing is written by just one actor. Joint statements are more common among some actors: Business associations (1.1) and public interest groups (1.2) tend to form coalitions with other actors to receive more attention by the ministries. 
Table 2 Bills discussed in ministries (2015 and 2016) and public hearings (later date). Source: Ministry's websites (BMU, BMI, BMF, BMG) and parliamentary committees' websites (Finance Committee, Committee on Health, Committee on Internal Affairs, Committee on the Environment, Nature Conversation, Housing and Nuclear Safety); own calculations

\begin{tabular}{|c|c|c|c|c|c|c|c|c|c|}
\hline \multirow[t]{2}{*}{ Actor type } & \multicolumn{2}{|c|}{$\begin{array}{l}\text { Written } \\
\text { state- } \\
\text { ments }\end{array}$} & \multicolumn{2}{|c|}{ Bills $^{\mathrm{a}}$} & \multicolumn{2}{|c|}{$\begin{array}{l}\text { Distinct } \\
\text { actors }\end{array}$} & \multirow{2}{*}{$\begin{array}{l}\text { Mean number } \\
\text { of statements } \\
\text { on a bill } \\
\varnothing\end{array}$} & \multirow{2}{*}{$\begin{array}{l}\text { Mean number } \\
\text { of statements } \\
\text { by actor } \\
\varnothing\end{array}$} & \multirow{2}{*}{$\begin{array}{l}\text { Mean number of } \\
\text { actors by state- } \\
\text { ment } \\
\varnothing\end{array}$} \\
\hline & $N$ & $\%$ & $N$ & $\%$ & $N$ & $\%$ & & & \\
\hline Ministries & 312 & - & 24 & - & 206 & - & 13.0 & 1.8 & 1.18 \\
\hline Unions & 21 & 6.7 & 12 & 50.0 & 6 & 2.9 & 1.8 & 3.5 & 1.00 \\
\hline $\begin{array}{r}\text { Business } \\
\text { groups }\end{array}$ & 148 & 47.4 & 19 & 79.2 & 106 & 51.5 & 7.8 & 1.9 & 1.32 \\
\hline $\begin{array}{l}\text { Occupational } \\
\text { groups }\end{array}$ & 51 & 16.4 & 16 & 66.7 & 20 & 9.7 & 3.2 & 2.6 & 1.00 \\
\hline Public interests & 60 & 19.2 & 14 & 58.3 & 46 & 22.3 & 4.3 & 1.4 & 1.05 \\
\hline Private firms & 10 & 3.2 & 4 & 16.7 & 10 & 4.9 & 2.5 & 1.00 & 1.00 \\
\hline Policy experts & 1 & 0.3 & 1 & 4.2 & 1 & 0.5 & 1.0 & 1.00 & 1.00 \\
\hline Others & 25 & 8.0 & 12 & 50.0 & 17 & 8.3 & 2.1 & 1.5 & 1.04 \\
\hline Parliament & 186 & - & 24 & - & 127 & - & 7.8 & 1.5 & 1.03 \\
\hline Unions & 19 & 10.2 & 11 & 45.8 & 8 & 6.3 & 1.7 & 2.4 & 1.00 \\
\hline $\begin{array}{c}\text { Business } \\
\text { groups }\end{array}$ & 41 & 22.0 & 17 & 70.8 & 22 & 17.3 & 2.4 & 2.1 & 1.10 \\
\hline $\begin{array}{l}\text { Occupational } \\
\text { groups }\end{array}$ & 9 & 4.8 & 8 & 33.3 & 5 & 3.9 & 1.1 & 1.8 & 1.00 \\
\hline Public interests & 29 & 15.6 & 11 & 45.8 & 26 & 20.5 & 2.6 & 1.2 & 1.03 \\
\hline Private firms & 8 & 4.3 & 7 & 29.2 & 8 & 6.3 & 1.1 & 1.0 & 1.00 \\
\hline Policy experts & 44 & 23.7 & 19 & 79.2 & 31 & 24.4 & 2.4 & 1.5 & 1.00 \\
\hline Others & 36 & 19.4 & 18 & 75.0 & 27 & 21.3 & 2.00 & 1.3 & 1.00 \\
\hline Overall & 498 & - & 24 & - & 314 & - & 20.8 & 1.78 & 1.12 \\
\hline
\end{tabular}

${ }^{\mathrm{a}}$ Total number and proportion of bills in which at least one actor (per actor type) was active

Next, we zoom in on the 24 bills on which both ministries and parliamentary committees held consultations. We will analyze the differences between actor types, regarding their participation in these consultations that took place in different stages of the legislative process.

The number of distinct actors that submitted statements on the 24 bills varies greatly between ministries (206) and parliament (127). Only 6.1\% of the actors (13) took part in both parliamentary and government consultations. In contrast to the results shown in the first table, we only find co-authored statements in the ministerial consultations (1.3\% of all distinct statements). When comparing actors' overall activity, Table 2 illustrates considerable differences between actor types, both within the same branch and across the branches. Business groups are the predominant actor type at ministerial level, constituting $51.5 \%$ of all distinct actors who submitted written statements. They wrote $47.4 \%$ of all submitted statements and commented on $79.2 \%$ of all ministerial bills. 
Their mean number of statements on a bill is 10.2 statements when adding the mean numbers of statements given to ministries and to parliament confirms their high level of activity. Major reasons for the predominance of business interests are the vast number of groups representing business interests and their greater financial resources to lobby government. The second most frequent actor type at ministerial level are public interest groups (22.3\% of all actors, $19.2 \%$ of all statements), followed by occupational groups, the latter of which submitted $16.4 \%$ of all statements while only constituting only $9.7 \%$ of all distinct actors. Unions account only for $2.9 \%$ of the actors submitting statements to ministries, but tend to submit the largest number of statements by actor (3.5). The German union sector has a strongly corporatist structure: It consists of a limited number of hierarchically ordered and functionally differentiated unions that have a certain level of representational monopoly (Schmitter 1977).

In contrast, the dominant actor type in parliamentary hearings is the policy expert (24.4\%, compared to $0.49 \%$ in ministries). Committees asked experts to comment on nearly $80 \%$ of all bills. Regarding interest organizations, the share of business groups and public interest groups is fairly balanced. The share of business interests amounts to $17.3 \%$ of all actors. Business interests submitted $22.0 \%$ of all statements, while public interest groups have a share of $20.5 \%$ among all distinct actors. They contributed $15.6 \%$ of all statements. Unions and private firms have each a share of $6.3 \%$ of all distinct actors with unions submitting more statements.

Our illustrative findings correspond well with those found in an analysis of the interaction between parliamentary committees and external actors in the UK, Denmark and the Netherlands (Pedersen et al. 2015). This study shows that open consultations without prior invitation tend to increase the dominance of interest groups over other actor types, while consultations based on invitations increase the diversity of the actor composition and include a greater variety of actor types such as experts and private companies.

\section{Conclusion}

This research note gives an overview about how written statements submitted to consultations can serve as a data source for interest group scholarship.

We used the German case as an illustrative example of how written statements can help to identify the participation of actors in public policy-making. Our analysis of collected written statements submitted to the two branches of government points to different patterns. In response to their rather open calls, German ministries mostly receive written statements from business groups, whereas the parliamentary committees often invite policy experts to obtain evidence that is not only independent from interest groups but also from the ministerial bureaucracy. At the same time, in our sample, ministries consult on fewer bills than parliamentary committees and when doing so, they seem to favor interest groups over policy experts. This confirms previous findings in the literature on interest groups (Binderkrantz et al. 2015; Beyers 2004; Pedersen et al. 2015). However, here we need to take into consideration 
that the ministerial bureaucracy can also solicit expert advice when preparing a bill outside public consultations.

These descriptive analyses point to further research avenues. The used data sources enable researchers to analyze representation in open as well as in closed consultations. While an open consultation informs us about the population of actors which seek to influence legislation, a close consultation tells us whose policy advice political institutions seek and with whom they might be closely aligned. Studying written submissions enables us to survey whether access to government and parliament is cumulative or whether the two branches consult different actors. Furthermore, retrieval of positions in the statements enables researchers to assess interest groups' influence on legislation by measuring their success in preference attainment and their impact on legislative change.

In sum, analyzing written statements sheds light on issues such as public participation and political representation, in the sense that it can show whether access to political arenas is skewed in a certain direction and whether certain interests prevail more often than others. Interest groups and other actors connect a variety of people to the decision-making process (Røed and Hansen 2018). The analysis of statements can be useful when studying the mobilization of interests.

They can also aid in the business of clarifying, when, where, how and why actors engage in coalitions or participate in certain policies and not in others.

Acknowledgements Open Access funding provided by Projekt DEAL. The authors thank Sonja Grabarczyk, Anne Knappe, Verena Leyendecker, Jule Scholten, Anna Reuter, Romy Trösken, Rebeccaa Westerholt and Jonas Wöll for their meticulous coding.

Open Access This article is licensed under a Creative Commons Attribution 4.0 International License, which permits use, sharing, adaptation, distribution and reproduction in any medium or format, as long as you give appropriate credit to the original author(s) and the source, provide a link to the Creative Commons licence, and indicate if changes were made. The images or other third party material in this article are included in the article's Creative Commons licence, unless indicated otherwise in a credit line to the material. If material is not included in the article's Creative Commons licence and your intended use is not permitted by statutory regulation or exceeds the permitted use, you will need to obtain permission directly from the copyright holder. To view a copy of this licence, visit http://creativecommons.org/licen ses/by/4.0/.

\section{References}

Baroni, L., B.J. Carroll, A. William Chalmers, L.M.M. Marquez, and A. Rasmussen. 2014. Defining and Classifying Interest Groups. Interest Groups \& Advocacy 3(2): 141-159.

Baumgartner, F.R., J. Berry, M. Hojnacki, D.C. Kimball, and B.L. Leech. 2009a. Lobbying and Policy Change. Who Wins, Who Loses, and Why. Chicago: University of Chicago Press.

Baumgartner, F.R., H.A. Larsen-Price, B.L. Leech, and P. Rutledge. 2009b. Congressional and Presidential Effects on the Demand for Lobbying. Political Research Quarterly 64(1): 3-16.

Beyers, J. 2004. Voice and Access. Political Practices of European Interest Associations. European Union Politics 5(2): 211-240.

Beyers, J., L.C. Bonafont, A. Dür, R. Eising, D. Fink-Hafner, D. Lowery, C. Mahoney, W. Maloney, and D. Naurin. 2014. The INTEREURO Project: Logic and Structure. Interest Groups \& Advocacy 3(2): $126-140$. 
Beyers, J., R. Eising, and W. Maloney. 2008. Researching Interest Group Politics in Europe and Elsewhere: Much We Study, Little We Know? West European Politics 31(6): 1103-1128.

Binderkrantz, A., P.M. Christiansen, and H.H. Pedersen. 2015. Interest Group Access to the Bureaucracy, Parliament and the Media. Governance 28(1): 95-112.

Boräng, F., R. Eising, H. Klüver, C. Mahoney, D. Naurin, D. Rasch, and P. Rozbicka. 2014. Identifying Frames: A Comparison of Research Methods. Interest Groups \& Advocacy 3(2): 188-201.

Bunea, A., and R. Ibenskas. 2015. Quantitative Text Analysis and the Study of EU Lobbying and Interest Groups. European Union Politics 16(3): 429-455.

Burstein, P., and C.E. Hirsh. 2007. Interest Organizations, Information, and Policy Innovation in the U.S. Congress. Sociological Forum 22(2): 174-199.

Cross, J.P., R. Eising, H. Hermansson, and F. Spohr. 2019. Business Interests, Public Interests, and Experts in Parliamentary Committees: Their Impact on Legislative Change in the German Bundestag. West European Politics. https://doi.org/10.1080/01402382.2019.1672025.

Dhungel, A.-K., and E. Linhart. 2014. Interessenvermittlung in den Ausschüssen des Deutschen Bundestages. Zeitschrift für Parlamentsfragen 45(4): 743-762.

Dür, A. 2008. Measuring Interest Group Influence in the EU: A Note on Methodology. European Union Politics 9(4): 559-576.

Dür, A., P. Bernhagen, and D. Marshall. 2015. Interest Group Success in the European Union: When (and Why) Does Business Lose? Comparative Political Studies 48(8): 951-983.

Eising, R., D. Rasch, and P. Rozbicka. 2015. Institutions, Policies, and Arguments: Context and Strategy in EU Policy Framing. Journal of European Public Policy 22(4): 516-533.

Eising, R., D. Rasch, P. Rozbicka, D. Fink-Hafner, M. Hafner-Fink, and M. Novak. 2017. Who Says What to Whom? Alignments and Arguments in EU Policy-Making. West European Politics 40(5): 957-980.

Eising, R., and F. Spohr. 2017. The More, the Merrier? Interest Groups and Legislative Change in the Public Hearings of the German Parliamentary Committees. German Politics 26(2): 314-333.

Gründinger, W. 2012. Lobbyismus im Klimaschutz. Die nationale Ausgestaltung des europäischen Emissionshandelssystems. Wiesbaden: VS Verlag für Sozialwissenschaften.

Klüver, H. 2011. The Contextual Nature of Lobbying: Explaining Lobbying Success in the European Union. European Union Politics 12(4): 483-506.

Klüver, H. 2013. Lobbying as a Collective Enterprise: Winners and Losers of Policy Formulation in the European Union. Journal of European Public Policy 20(1): 59-76.

Klüver, H., and C. Mahoney. 2015. Measuring Interest Group Framing Strategies in Public Policy Debates. Journal of Public Policy 35(2): 223-244.

Krippendorff, K. 2004. Content Analysis Reader. An Introduction to Its Methodology. Thousand Oaks: Sage Publications.

Manwaring, R. 2014. The Search for Democratic Renewal. The Politics of Consultation in Britain and Australia. Manchester: Manchester University Press.

Pedersen, H.H., D. Halpin, and A. Rasmussen. 2015. Who Gives Evidence to Parliamentary Committees? A Comparative Investigation of Parliamentary Committees and Their Constituencies. The Journal of Legislative Studies 21(3): 408-427.

Rasch, D. 2018. Lobbying Success in the European Union. The Role of Information and Frames. New York, NY: Routledge.

Rasmussen, A. 2015. Participation in Written Government Consultations in Denmark and the UK: System and Actor-Level Effects. Government and Opposition 50(2): 271-299.

Rasmussen, A., and B.J. Carroll. 2014. Determinants of Upper-Class Dominance in the Heavenly Chorus: Lessons from European Union Online Consultations. British Journal of Political Science 44(2): $445-459$.

Røed, M., and V.W. Hansen. 2018. Explaining Participation Bias in the European Commission's Online Consultations: The Struggle for Policy Gain Without Too Much Pain. Journal of Common Market Studies 56(6): 1446-1461.

Sabatier, P., and D. Whiteman. 1985. Legislative Decision Making and Substantive Policy Information: Models of Information Flow. Legislative Studies Quarterly 10(3): 395-421.

Sack, D., and S. Fuchs. 2014. Wirtschaftskammern und Parlamente. In Interessengruppen und Parlamente, ed. T. von Winter and J. von Blumenthal. Wiesbaden: VS Verlag für Sozialwissenschaften.

Schmitter, P.C. 1977. Modes of Interest Intermediation and Models of Societal Change in Western Europe. Comparative Political Studies 10(1): 7-38. 
Schwartz, F.J. 1998. Advise and Consent. The Politics of Consultation in Japan. Cambridge: Cambridge University Press.

Wonka, A. 2016. The Party Politics of the Euro Crisis in the German Bundestag: Frames, Positions and Salience. West European Politics 39(1): 125-144.

Yackee, S.W. 2006. Sweet-Talking the Fourth Branch: The Influence of Interest Group Comments on Federal Agency Rulemaking. Journal of Public Administration Research and Theory 16(1): 103-104.

Publisher's Note Springer Nature remains neutral with regard to jurisdictional claims in published maps and institutional affiliations. 